\title{
Xeric big sagebrush, a new subspecies in the Artemisia tri- dentata complex
}

\author{
ROGER ROSENTRETER AND RICK G. KELSEY
}

\begin{abstract}
In 1970 a xeric form of mountain big sagebrush (Artemisia tridentata ssp. vaseyana (Rydb.) Beetle) was reported in west central Idaho. Observations of morphology, habitat, and ecology, and analyses of foliage chemical components, clearly indicate these plants represent a new subspecies (xericensis) in the big sagebrush complex. It grows at lower elevations, $762-1,524 \mathrm{~m}(2,500-5,000 \mathrm{ft})$ and drier environments, $305-560 \mathrm{~mm}(12-22 \mathrm{in})$ precipitation, than most mountain big sagebrush, and is found on basaltic foothill soils often in association with bluebunch wheatgrass (Agropyron spicatum (Pursh) Scribn. \& Smith). In addition to soil type, the radiate growth form and a more branched paniculate inflorescence are $\mathbf{2}$ morphological characteristics useful in separating ssp. xericensis from ssp. vaseyana. It contains higher concentrations of crude protein (10.4\%), phosphorus $(0.3 \%)$, and total volatlles, and lower concentrations of tannins and total phenols than mountain big sagebrush. Distinct chromatograms were obtained for both subspecies when extracts were analyzed by gas and high performance liquid chromatography. Leaf morphology and nuorescence of leaf water extracts are useful characters for separating ssp. xericensis from ssp. tridentata. The chemical data, in combination with morphology and ecology, suggest this new subspecies was initially derived by hybridization of ssp. tridentata and ssp. vaseyana.
\end{abstract}

Key Words: mountain big sagebrush, taxonomy, chemotaxonomy, terpenes, phenols, indicator species

Big sagebrush (Artemisia tridentata Nutt.), described by Nuttall in 1841, has been separated and revised into several species and subspecies as our knowledge and studies of these taxa have grown. The Artemisia tridentata complex, as recognized by Beetle (1960), Beetle and Young (1965), and Goodrich et al. (1985), includes subspecies tridentata (basin big sagebrush), vaseyana (Rydb.) Beetle (mountain big sagebrush), wyomingensis Beetle and Young (Wyoming big sagebrush), and spiciformis (Osterhout) Goodrich and McArthur (subalpine big sagebrush), respectively. Winward (1970) mentioned xericensis as a form growing at elevations normally supporting ssp. wyomingensis and ssp. tridentata, but chemically and phenologically more similar to ssp. vaseyana. Winward and Tisdale (1977) referred to this taxon as form " $X$ " in their treatment of the big sagebrush complex in Idaho. They also provided additional ecological information, relative to the other subspecies. Hironaka et al. (1983) recognized the distinctly different habitat and morphology of these plants and described 2 habitat types for Artemisia tridentata "xericensis" in southern Idaho. The USDA, Soil Conservation Service has recognized it as a distinct

\footnotetext{
The authors are botanist, Bureau of Land Management, Idaho State Office, 3380 Americana Terrace, Boise 83706; and research scientist, USDA, Forest Service, Pacific Northwest Forest and Range Experiment Station, 3200 Jefferson Way, Corvallis, Ore. 97331

We thank Ann DeBolt, Paul Seronko, Jim Wernz, and Liz Gerson, for assisting in the field, with soil interpretation, mineral analysis, and in the laboratory, respectively. Special thanks are given to Tom Sabin for his valuable help with the statistics, and to Drs. Al Winward and Durant McArthur for reviewing the manuscript. We also wish to acknowledge the late Mel Morris for inspiration and keen interest in sagebrush, which apparently rubbed off on both of us.

Manuscript accepted 21 July 1990.
}

type of sagebrush for the last 10 years. They have named and described 3 xericensis ecological sites, in habitats where it is one of the dominant taxa (USDA, Soil Conservation Service in edit). Bunting et al. (1987) separated xericensis (species "X") from the other big sagebrush subspecies because of its environmental characteristics and general fire response.

\section{Methods}

\section{Field Studies}

Specimens of Artemisia tridentata were collected during October and November, 1987, in Washington and Gem counties of west central Idaho, in areas where xeric big sagebrush was suspected to occur. Field identification and herbarium collections in late summer and autumn are preferred because at this time of year sagebrush subspecies are more easily distinguished from each other by the relative position of their flower stalks within the crown. Populations were evaluated morphologically, and periodically leaves were placed in water and fluoresced with a battery powered long-wave ultraviolet light (UV) to help confirm their identity (Stevens and McArthur 1974, McArthur et al. 1981). All populations were tentatively identified in the field, and observations were made on the phenology, ecology, and distribution of each taxon.

A total of 22 sites of ssp. xericensis or ssp. vaseyana were sampled and evaluated. Voucher herbarium collections were made at each site. An additional 10 grams of leaves, collected for chemical analysis, were sealed in a double layer of ziplocking plastic bags, frozen with dry ice, and transported to a freezer until needed. These leaves were gathered from various parts of the canopy of several different shrubs in a homogeneous stand. Collection sites extended across the geographic and elevational ranges of both taxa within the area sampled. We included 2 field specimens that were possible intermediates, or introgressive hybrid specimens, from transitional soils and habitat types. Local biologists and soil scientists were interviewed to gather additional ecological and locational data. Geographic distribution was determined from voucher collections, soil survey data correlated to actual soil profiles (USDA, Soil Conservation Service in edit), and observations in the field.

\section{Sample Preparation}

Subsamples of frozen leaves were oven dried 24 hours at $60^{\circ} \mathrm{C}$, then ground to pass a 60 -mesh screen in a Wiley mill. They were stored at room temperature in sealed glass vials, redried and cooled in a desiccator prior to weighing for each analysis. This material was used for all analyses except the monoterpenes.

\section{Crude Protein and Mineral Composition}

Dried, ground subsamples were submitted to the Plant Analysis Laboratory, Oregon State University for analyses. Crude protein was estimated by multiplying percent nitrogen as determined by the methods of Schuman et al. (1973), by 6.25. Twenty-one mineral elements were analyzed with a Jarrel-Ash ICAP-9000 using $1.0 \mathrm{~g}$ subsamples ashed at $500^{\circ} \mathrm{C}$ for 6 hours in porcelain crucibles, and then prepared by a slightly modified method of Jones (1977).

\section{Phenolics}

Three nonexclusive categories of phenolics were analyzed in the 


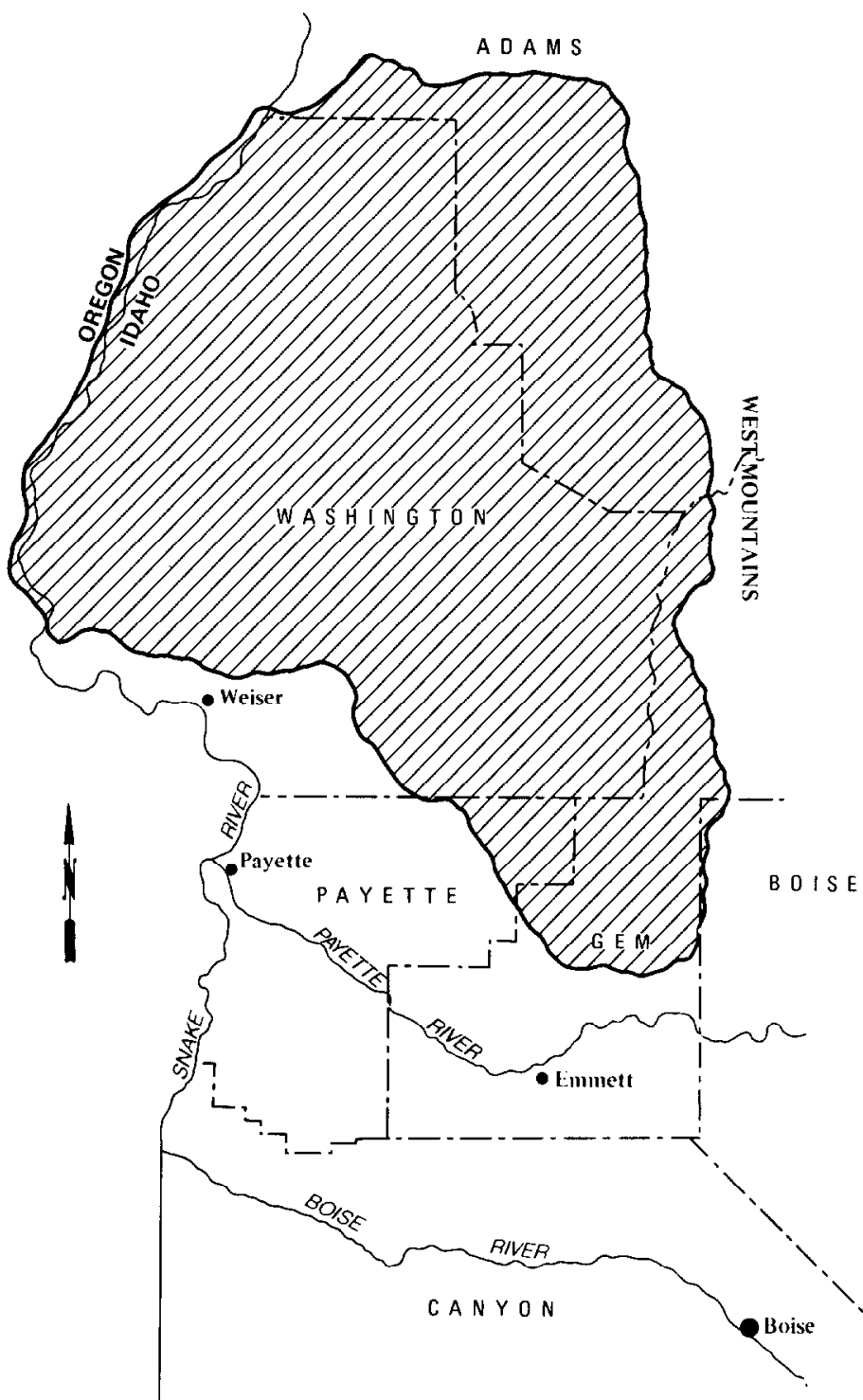

Fig. 1. Distribution of xeric big sagebrush in west central Idaho.

dried tissues: coumarins and flavonoids, total phenols, and tannins. Coumarins and flavonoids were extracted from 100 milligrams of tissue covered with $5 \mathrm{ml}$ of $70 \%$ aqueous ethanol for 15 hours. The solvent contained 2,5-dihydroxybenzoic acid (DHBA) as an internal standard. After filtering (nylon 66 membrane, 0.45 $\mu$ ), the extracts were analyzed by high performance liquid chromatography (HPLC). The column used was an Alltech $250 \times 4.6 \mathrm{~mm}$ Lichrosorb RP-18 (5 $\mu)$. Other chromatographic conditions were as reported by Vande Casteele et al. (1982), except for our 1.0 $\mathrm{ml} / \mathrm{min}$ solvent flow rate. Compound concentrations were calculated with a response factor of 1 relative to DHBA and reported as DHBA equivalents/g dry weight. Some compounds were tentatively identified by peak enrichment with reference standards.

Total phenols were analyzed in duplicate extracts prepared as described for coumarins and flavonoids above, but without an internal standard in the solvent. Fifty $\mu \mathrm{l}$ aliquotes were diluted with $1,950 \mu \mathrm{l}$ of $\mathrm{H}_{2} \mathrm{O}$ before adding Folin-Ciocalteau phenol reagent as described by Julkunen-Tiitto (1985). Zero was set on the spectrophotometer with distilled $\mathrm{H}_{2} \mathrm{O}$ and a standard curve prepared with phenol. Concentrations were calculated as $\mathrm{mg} / \mathrm{g}$ dry weight of phenol equivalents.

Tannins were analyzed by radial diffusion (Hagerman 1987) using duplicate subsamples (100 $\mathrm{mg}$ ) of the dried, ground leaves extracted with $0.5 \mathrm{ml}$ of $70 \%$ aqueous ethanol for 15 hours. Puri- fied tannic acid (Hagerman and Klucher 1986) was used as a standard.

\section{Monoterpenes and Other Volatiles}

Frozen fresh leaves were warmed to room temperature while sealed in their plastic storage bags. A representative subsample was frozen with liquid $\mathrm{N}_{2}$, and cleaned by removing stems and discolored leaves, before grinding with a mortar and pestle. The powder was transferred to vials and sealed while warming to room temperature. Approximately $500 \mathrm{mg}$ were accurately weighed and extracted by shaking for 60 minutes with $3.0 \mathrm{ml} \mathrm{CHCl}_{3}$ containing limonene as internal standard. Particulates were removed by filtering through a nylon 66 membrane $(0.45 \mu)$ before sealing in vials with solvent resistant caps. Moisture content of the freshly ground tissue was measured in triplicate by drying subsamples overnight at $100^{\circ} \mathrm{C}$ and cooling in a desiccator prior to weighing.

The extracts were analyzed with a gas chromatograph (GC) equipped with a Supelcowax 10 fused silica capillary column ( $30 \mathrm{~m}$ $\times 0.32 \mathrm{~mm}$ i.d.), 1:50 split, helium carrier gas, and a flame ionization detector. The oven temperature was programmed from $60^{\circ} \mathrm{C}$ to $220^{\circ} \mathrm{C}$, increasing $5^{\circ} \mathrm{C} / \mathrm{min}$ and holding $220^{\circ} \mathrm{C}$ for 15 minutes. Injector and detector temperatures were $250^{\circ} \mathrm{C}$. Because of the waxy components extracted by $\mathrm{CHCl}_{3}$, in some instances it was necessary to clean the column between samples, by including a blank run without injecting a sample. Concentrations of each component were calculated as $\mu \mathrm{g} / \mathrm{g}$ dry weight using the response factor of $\alpha$-pinene for all compounds with retention times less than limonene, and a second response factor (an average for citronellol, fenchone, and geranyl acetate) for all components with retention times greater than limonene. Compounds present in at least 1 of the 22 samples, at a concentration of $250 \mu \mathrm{g} / \mathrm{g}$ or above, were assigned a number and utilized in the analysis. The concentration of each numbered compound was recorded in all samples even if below 250 $\mu \mathrm{g} / \mathrm{g}$. Zero was assigned numbered compounds at low concentrations, failing to reach a predetermined minimal area. Compounds were identified by peak enrichment with standards and $\mathrm{GC} /$ mass spectrometry.

\section{Statistical Analysis}

To help validate the distinctness of spp. xericensis plants from ssp. vaseyana plants, 8 chemical components (total coumarins and flavonoids, total phenols, tannins, total GC volatiles, crude protein, $\mathbf{P}, \mathbf{K}$, and $\mathbf{C a}$ ) were selected for analysis by the multivariate Hotelling's $\mathrm{T}^{2} \mathrm{t}$-test from the BMDP Statistical Software Package (Snookne and Forsythe 1988).

Stepwise discriminant analyses were conducted with 3 separate sets of data: the 75 volatile compounds from GC chromatograms, the 30 coumarin and flavonoid compounds from HPLC chromatograms, and the 21 mineral elements analyzed by ICAP. In each analysis individual samples were classified into subspecies groups by resubstitution and cross-validation using the computed linear discriminant function.

\section{Results}

\section{Field Studies}

This new taxon is similar to ssp. vaseyana in its leaf shape and blue fluorescence under UV light when placed in water (Stevens and McArthur 1974, McArthur et al. 1981), or alcohol (Winward and Tisdale 1969, Winward 1980). Subspecies xericensis flower stalks, however, do not give the crown an even-topped appearance characteristic of ssp. vaseyana. It differs by growing on drier and warmer soils with a taller, more radiate growth form, and a more branched paniculate inflorescence (Table 1). Characteristics separating ssp. xericensis from ssp. tridentata are much more distinct. The latter has a narrower leaf, no blue UV fluorescence in 
Table 1. Characteristics useful in separating 3 subspecies of big sagebrush.

\begin{tabular}{|c|c|c|c|}
\hline \multirow[b]{2}{*}{ Characteristic } & \multicolumn{3}{|c|}{ Subspecies } \\
\hline & vaseyana & xericensis & tridentata \\
\hline Growth form & basal branching & radiate & erect \\
\hline $\begin{array}{l}\text { Crown shape with } \\
\text { flower stalks }\end{array}$ & even-topped & uneven-topped & uneven-topped \\
\hline Inflorescence & $\begin{array}{l}\text { racemose- } \\
\text { paniculate }\end{array}$ & $\begin{array}{l}\text { paniculate- } \\
\text { radiate }\end{array}$ & paniculate \\
\hline Flowering begins & early August & early August & late August \\
\hline Leaf shape & $\begin{array}{l}\text { broadly } \\
\text { cuneate }\end{array}$ & $\begin{array}{l}\text { broadly } \\
\text { cuneate }\end{array}$ & narrow \\
\hline $\begin{array}{l}\text { Leaf length/ } \\
\text { width ratio }\end{array}$ & 4.0 or less & 4.0 or less & over 4.0 \\
\hline $\begin{array}{l}\text { Leaf UV color } \\
\text { in water } \\
\text { or alcohol }\end{array}$ & $\begin{array}{l}\text { blue } \\
\text { blue-cream }\end{array}$ & $\begin{array}{l}\text { blue } \\
\text { blue-cream }\end{array}$ & $\begin{array}{l}\text { none } \\
\text { red/brown }\end{array}$ \\
\hline $\begin{array}{l}\text { Elevation } \mathrm{m} \\
\text { Elevation } \mathrm{ft}\end{array}$ & $\begin{array}{l}1219-2740 \\
4000-9000\end{array}$ & $\begin{array}{l}760-1370 \\
2500-4500\end{array}$ & $\begin{array}{l}305-2140 \\
1000-7000\end{array}$ \\
\hline Soil temperature & cryic-frigid & mesic & frigid-mesic \\
\hline Soil moisture & udic-xeric & xeric & aridic-xeric \\
\hline
\end{tabular}

water or alcohol, a more erect form, and begins flowering later in the season. On sites where ssp. xericensis has been found growing with ssp. vaseyana the morphological characteristics of each taxon have remained distinct.

Xeric big sagebrush is commonly found on well-drained, moderately deep, mesic temperature and xeric moisture rated soils, derived from Columbia River basalt. Its geographic distribution appears to be edaphically and climatically controlled, occurring between 762 and $1,524 \mathrm{~m}$ in west central Idaho (Fig. 1). The soils are dominated by Argixolls at the subgroup level of soil taxonomy, with depths ranging from $45 \mathrm{~cm}$ to more than $150 \mathrm{~cm}$. The shal- lower soils are associated with very fractured basalt bedrock, typically with thick $(17.5-25.0 \mathrm{~cm})$ dark surface horizons, varying in texture from loams to clay loams. The subsoil is dark to medium dark brown and varies in texture from clay loam to clay, with the section generally averaging $<35 \%$ clay content (USDA, Soil Conservation Service in edit). For this study xeric big sagebrush was collected from populations in Washington and Gem counties and was observed to be growing on the rangelands of the neighboring Boise and Payette counties. It was not found at several sites examined in adjacent Oregon, but may be discovered with a more extensive survey.

\section{Comparison of Chemical Components between Subspecies}

Data from the chemical analysis, particularly the GC and HPLC chromatograms, provided further evidence that the plants being identified as ssp. xericensis were sufficiently distinct to warrant separation from ssp. vaseyana, and recognition at the subspecies level. To verify this statistically, 8 chemical components (Table 2) were selected for comparison by the multivariate Hotelling's $\mathrm{T}^{2}$ $\mathrm{t}$-test. This was complicated somewhat by the discovery during chemical analysis that one of the samples identified as spp. vaseyana in the field was chemically identical to plants belonging to the ssp. xericensis group. To validate the reclassification of the sample Hotelling's $\mathrm{T}^{2} \mathrm{t}$-test was performed on 3 separate sets of samples, once with the suspect plant included with the ssp. vaseyana, once with it in the ssp. xericensis group, and once without it in either group. Regardless of where the questionable sample was included, all 3 tests indicated significant differences between the 2 groups, but the $p$-value was smallest when this sample was included with ssp. xericensis, confirming its identity. This was supported by the classification of samples in the discriminant analysis.

When this sample was properly identified as ssp. xericensis, 5 of the 8 chemical components were significantly different from the ssp. vaseyana group (Table 2). Subspecies xericensis plants con-

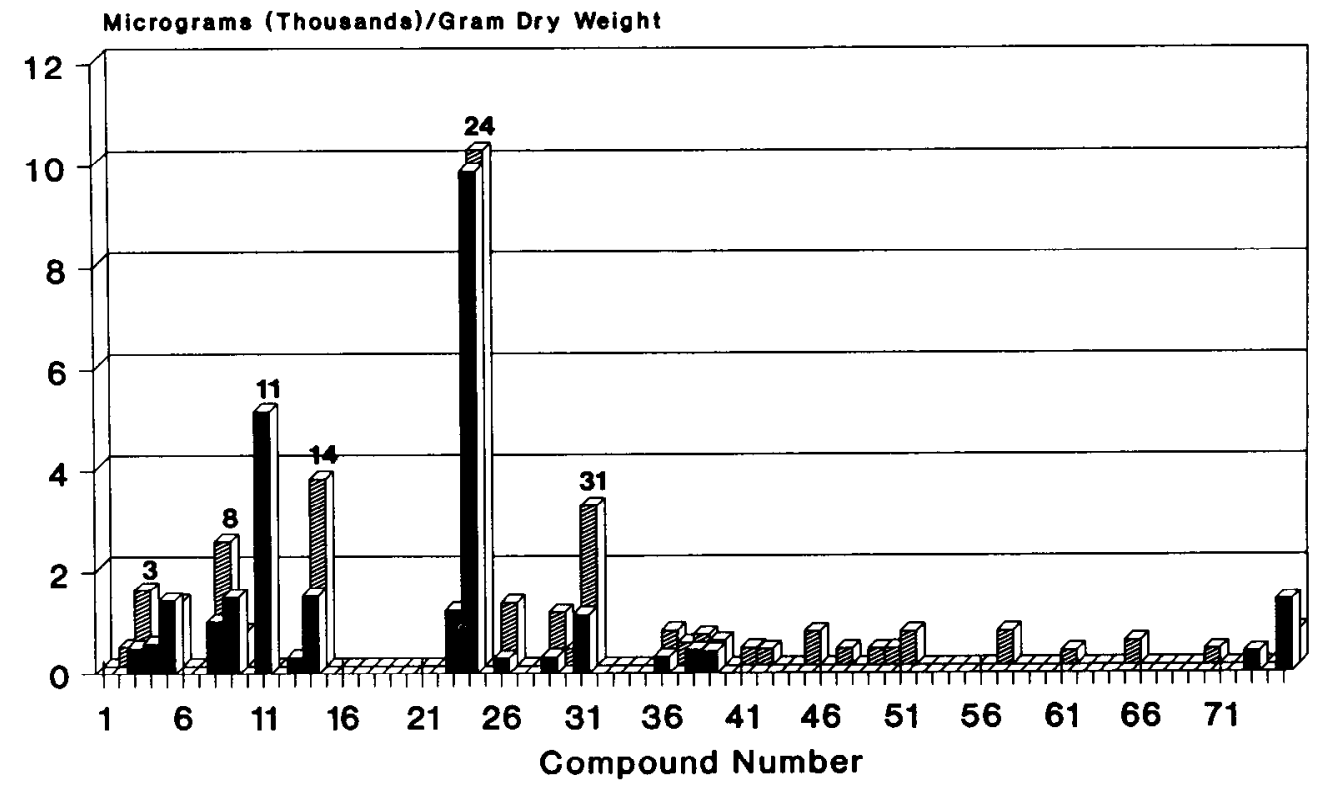

ssp. vaseyana

Fig. 2. Average concentration of major (present in at least half of the samples of a taxa at a concentration of $250 \mu \mathrm{g} / \mathrm{g}$ dry weight, or greater) volatile compounds in ssp. xericensis and ssp. vaseyana, measured by GC. Compounds identified by peak enrichment with known standards and/or GC/mass spectrometry are $1=$ methyl butene, $2=$ acetone, $3=$ methacrolein, $4=\alpha$-pinene, $5=$ camphene, $6=\beta$-pinene, $8=$ artemiseole, $9=1,8$-cineole, $10=p$-cymene, $11=$ artemisia ketone, $13=$ yomogi alcohol, 14= artemisia acetate/methyl santolinate, $23=$ artemisia alcohol, $24=$ camphor, $25=$ linalool, $29=$ bornyl acetate, 38= borneol. 
Table 2. Average concentrations of chemical components in ssp. xericensis and ssp. vaseyana. Statistical comparisons were made with the multivariate Hotelling $\mathbf{T}^{2}$ t-test.

\begin{tabular}{|c|c|c|c|c|c|}
\hline \multirow{3}{*}{$\begin{array}{l}\text { Component } \\
\text { Total coumarins } \\
\text { and flavonoids } \\
\text { (DHBA eq } / g)^{1}\end{array}$} & \multicolumn{4}{|c|}{ Subspecies } & \multirow[b]{2}{*}{$p$-Value } \\
\hline & \multicolumn{2}{|c|}{$\begin{array}{r}\text { xericensis } \\
(n=12)\end{array}$} & \multicolumn{2}{|c|}{$\begin{array}{l}\text { vaseyana } \\
(\mathrm{n}=10)\end{array}$} & \\
\hline & \multicolumn{2}{|c|}{$1710.5(396.8)^{2}$} & \multicolumn{2}{|c|}{$1644.6(457.1)$} & 0.725 \\
\hline $\begin{array}{l}\text { Total phenols } \\
(\mathrm{mg} / \mathrm{g})^{3}\end{array}$ & 44.5 & (7.5) & 60.4 & $(10.2)$ & 0.001 \\
\hline Tannins $(\mathrm{mg} / \mathrm{g})^{4}$ & 6.0 & $(0.3)$ & 6.7 & $(0.7)$ & 0.011 \\
\hline $\begin{array}{l}\text { Total GC volatiles } \\
(\mathrm{mg} / \mathrm{g})\end{array}$ & 42.9 & (12.3) & 32.2 & $(5.7)$ & 0.016 \\
\hline $\begin{array}{l}\text { Crude protein }(\%) \\
\mathrm{P}(\%) \\
\mathrm{K}(\%) \\
\mathrm{Ca}(\%)\end{array}$ & $\begin{array}{r}10.4 \\
0.3 \\
1.1 \\
0.6\end{array}$ & $\begin{array}{l}(0.7) \\
(0.0) \\
(0.2) \\
(0.1)\end{array}$ & $\begin{array}{l}9.3 \\
0.2 \\
1.0 \\
0.5\end{array}$ & $\begin{array}{l}(0.9) \\
(0.1) \\
(0.2) \\
(0.1)\end{array}$ & $\begin{array}{l}0.004 \\
0.000 \\
0.263 \\
0.196\end{array}$ \\
\hline
\end{tabular}

12,5-Dihydroxybenzoic acid equivalents/g.

2Standard deviation in parentheses.

${ }^{3} \mathrm{Mg}$ of phenol equivalents/g.

${ }^{4} \mathbf{M g}$ of tannic acid equivalents $/ g$.

tained significantly greater quantities of crude protein, $P$, and total GC volatiles, but lower amounts of total phenols and tannins. There were no significant differences in $\mathrm{K}, \mathrm{Ca}$, and total concentration of coumarins and flavonoids. This provided strong support for the recognition of separate taxa. The separation was further strengthened by the GC and HPLC data described below.

\section{Monoterpenes and Other Volatiles}

Gas chromatograms were examined and grouped according to peak patterns. Those identified as ssp. vaseyana were readily separable from the ssp. xericensis. A total of 75 compounds from all 22 samples met our criteria for recognition and were used in the discriminate analysis. Figure 2 shows the average concentrations for the major volatile constituents in each group. There were 17 major constituents in ssp. vaseyana compared to 29 in ssp. xericensis. The latter plants contained greater quantities of methacrolein (peak 3), artemiseole (peak 8), artemisia acetate/methyl santolinate (peak 14), unknown compound 31, and other high temperature volatiles above camphor (peak 24). High concentrations of artemisia ketone (peak 11) was characteristic of ssp. vaseyana samples, as previously reported for this taxon growing in Oregon (Kelsey et al. 1983). Interestingly, camphor, present in similar concentrations, was the most abundant compound in both subspecies. Stepwise discriminate analysis by resubstitution and crossvalidation resulted in a $100 \%$ classification of the samples.

\section{Coumarins and Flavonoids}

Although the total concentrations of coumarins and flavonoids as measured by HPLC were not significantly different in Hotelling's $\mathrm{T}^{2}$ t-test, the chromatogram profiles were distinct (Fig. 3 ). Thirty compounds were recognized and used in the discriminate analysis. Subspecies xericensis samples were characterized by a low concentration of esculin (peak 1 ) and a high concentration of unknown compound 24. Although it is difficult to clearly see in Figure 3, in part due to the $Y$ axis scale, and the smoothing effect from averages, compounds 12 through 19 gave a diagnostic pattern for each group. Stepwise discriminate analysis by resubstitution and cross-validation resulted in $100 \%$ classification of the 2 sample groups.

\section{Mineral Composition}

The 21 minerals analyzed by ICAP were used to classify the samples by stepwise discriminate analysis. Using the resubstitution method, all samples were correctly classified; however, using crossvalidation 1 of the spp. xericensis, samples as classified with the spp. vaseyana samples. This was not the reclassified sample, or one of the 2 samples from intermediate habitats.

\section{Samples Difficult to Identify}

One sample from each subspecies had been collected from tran-

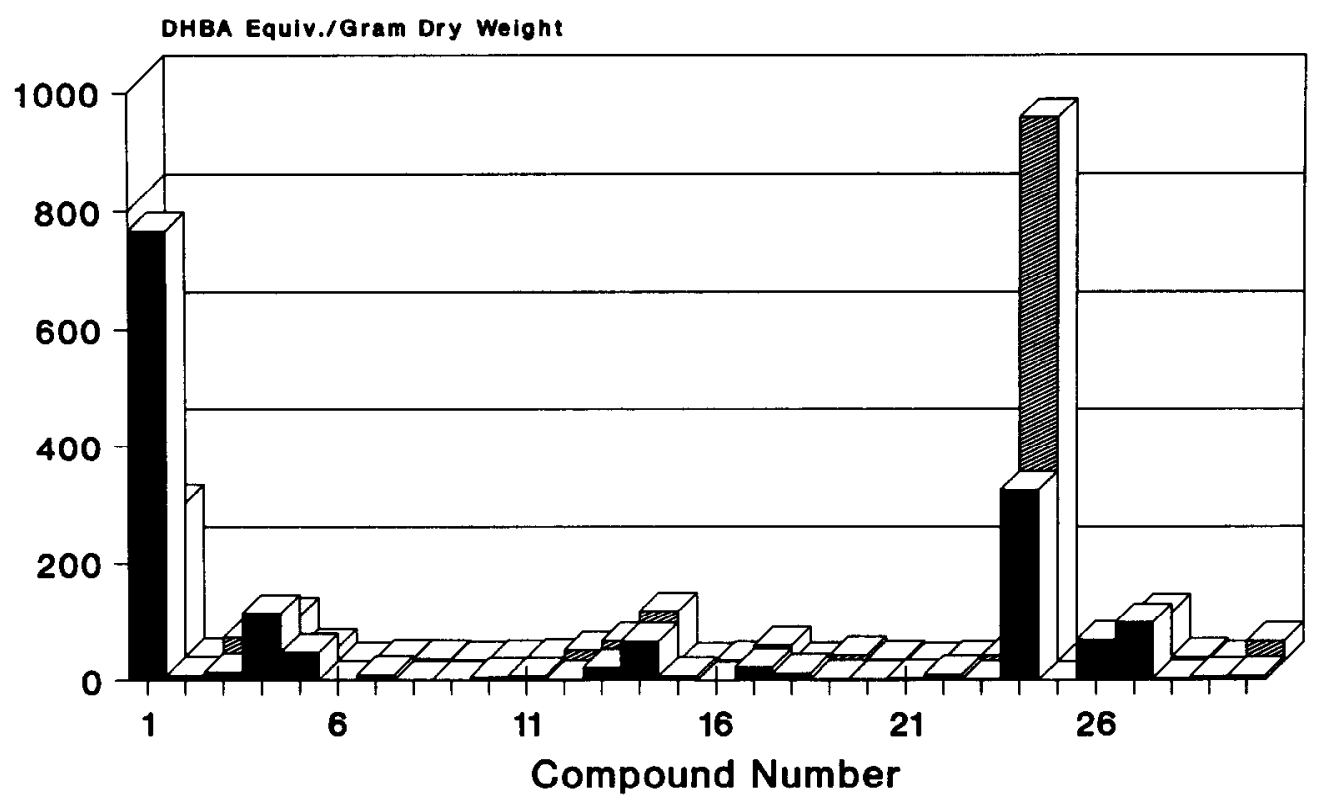

ssp. vaseyana

ssp. xericensis

Fig. 3. A comparison of coumarins and favonoids in ssp. xericensis and ssp. vaseyana, analyzed by HPLC. Compounds tentatively identified by peak enrichment with known standards are 1=esculin, 3=methyl esculin, 4=esculetin, 13=isoscopoletin, 27=luteolin/axillarin, 29=apigenin. 
sitional habitats where the morphological characteristics were not as distinct. The one tentatively identified as ssp. vaseyana in the field was easily confirmed as a member of this taxa by chemical analyses. The tentative ssp. xericensis sample was chemically most similar to the other samples in this subspecies, but both the GC and HPLC chromatograms indicated it was different. The GC chromatogram contained some major peaks, not present in any other samples from either taxa. There was nothing recognizable in the chromatograms, or other chemical data, to imply it was a hybrid with ssp. vaseyana. Discriminate analysis of the GC and HPLC data confirmed these 2 taxa were correctly classified.

\section{Nomenclature and Type Collections}

The name chosen for this taxon is Artemisia tridentata Nutt. subsp. xericensis Winward, subsp. nov. Artemisiae tridentatae subsp. vaseyanae similis sed ramis procerioribus erectioribusque, et inflorescentiis non candelabraceis differt. Artemisiae tridentatae subsp. tridentatae similis sed foliis latius cuneatis differt. Materia chemica distincta est.

The holotype was collected in Washington County, Idaho, (T13N, R5W, Sec. 35), $16 \mathrm{~km}$ northeast of Weiser near Mann Creek road, about $1.6 \mathrm{~km}$ west of Mann Creek Reservoir, on moderately deep clay loam soils, and elevation $914 \mathrm{~m}(3,000 \mathrm{ft})$. Specimens collected October 1987 by A. DeBolt and R. Rosentreter (No. 842) were deposited in the Snake River Plains Herbarium (SRP) at Boise State University in Boise, Idaho. Isotypes are deposited with the College of Idaho, Caldwell (CIC) and the Boise District, Bureau of Land Management Herbarium, Boise, Idaho.

\section{Discussion}

The results of all chemical analyses, in combination with the morphological and ecological differences observed in the field, provide strong evidence for the recognition of ssp. xericensis within the big sagebrush complex. Winward (1970) originally proposed this name and we have chosen to use it, in acknowledgement of his earlier work, and because it provides some description of the habitat (xeric soil moisture) where this taxon grows. It also avoids confusion that a name change would cause for management agencies currently using this terminology.

We have more narrowly defined the range of this taxon than did Winward (1970), or Winward and Tisdale (1977). Before it is extended and a more detailed map drawn (Fig. 1), further studies are required of the entire Artemisia tridentata complex in Idaho. The distribution of ssp. xericensis overlaps with mule deer winter range. This may be more than incidental since the protein content, and fair to good palatability, provide above-average winter nutrition for deer (Welch and McArthur 1979a). It also has a growth form that keeps the foliage accessible in snow.

The morphology and ecology of ssp. xericensis suggest a hybrid origin between ssp. vaseyana and ssp. tridentata. Natural and artificial hybrids of these 2 subspecies have been reported in Utah (McArthur et al. 1988), with putative hybrids exhibiting intermediate concentrations of parental chemical constituents, such as water soluble coumarins, methacrolein, and several monoterpenes. Winward's (1970) analysis of ssp. xericensis alcohol extracts by thin-layer chromatography support this hybrid theory, as do our chemical results. Although the nearest populations of basin big sagebrush were not analyzed chemically, the concentrations of crude protein and some of the diagnostic volatile compounds in xeric big sagebrush were indicative of an intermediate status, or more similar to quantities previously reported for ssp. tridentata than ssp. vaseyana. Basin big sagebrush plants have a higher winter crude protein content than mountain big sagebrush (Welch and McArthur 1979b). Crude protein levels in ssp. xericensis were greater than the levels in sympatric mountain big sagebrush popu- lations (Table 2), but not as high as that typically found in basin big sagebrush (Welch and McArthur 1979b). Like the ssp. tridentata in eastern Oregon (Kelsey et al. 1983) and Utah (McArthur et al. 1988), ssp. xericensis was characterized as having a higher concentration of methacrolein (peak 3) and much lower concentration of artemisia ketone (peak 1) than ssp. vaseyana.

Considering all the evidence, we conclude that ssp. xericensis has been derived from hybridization between ssp. tridentata and ssp. vaseyana followed by some ecological and geographic isolation, primarily from the ssp. tridentata gene pool. Subspecies xericensis appears to be a distinct genotype of Artemisia tridentata evolved to grow in xeric soil sites derived from basalt. The big sagebrush complex has been successful, in part due to its ability to exchange genetic material by hybridization and introgression (McArthur et al. 1988), thus maintaining genotypic variation with sufficient plasticity to allow the development of ecotypes. The genetic variability may have also helped minimize disease and herbivory, which weaken and limit less genetically diverse species.

\section{Management Implications}

In his 1986 publication, Tisdale noted that identification of sagebrush to subspecies rank was confined to cases where ecological differences were evident. Each subspecies of the Artemisia tridentata complex represents different ecological vegetation types and therefore are useful in determining land management decisions. We concur with Winward and Tisdale (1977) that the separation of big sagebrush to the subspecies rank assists in the recognition of (1) habitat types, (2) production potentials, (3) chemical content, and (4) palatability preference. Recognition of this fifth subspecies in the big sagebrush complex can improve the understanding and management of those sites where it occurs.

Xeric big sagebrush has been divided into 2 habitat types (Hironaka et al. 1983). The majority of its range is dominated by the Artemisia tridentata ssp. xericensis/Agropyron spicatum type, which receives more than $305 \mathrm{~mm}$ ( 12 in) of precipitation and has relatively warm summer temperatures. Cooler topographic positions and upper elevational sites grade into the ssp.xericensis/Festuca idahoensis habitat type. Above $1,372 \mathrm{~m}(4,500 \mathrm{ft})$ and in cooler topographical sites, ssp. vaseyana habitat types replaces the ssp. xericensis. The forb populations in the above habitats increase slightly with elevation.

Artemisia tridentata ssp. xericensis tends to increase in density if the understory is grazed. The deep soils encourage the shrubs to develop deep root systems, allowing annual grasses to occupy much of the upper soil profile, adjacent to, and beneath the shrub canopy. Fires in these habitat types burn very hot, killing associated perennial species. Bluebunch wheatgrass and rabbitbrush (Chrysothamnus Nutt. sp.) increases after burning, but on these sites it decreases due to the fire intensity.

Natural replacement after fire is by exotic medusahead (Elymus caputmedusae L.) and cheatgrass (Bromus tectorum L.), with successional trends toward squirreltail (Sitanion hystrix (Nutt.) Smith) and later, bluebunch wheatgrass. However, the lack of natural seed sources and weak seedling vigor of these perennials generally results in a persistent annual community of medusahead or cheatgrass. Direct seeding of rhizomatous grasses such as intermediate (Agropyron intermedium (Host) Beauv.) or western wheatgrass (Agropyron smithii Rydb.) have been successful and provide better soil protection than do bunch-grasses on these heavy textured soils.

\section{Literature Cited}

Beetle, A.A. 1960. A study of sagebrush. The section Tridentatae of Artemisia. Agr. Exp. Sta. Bull. 368. Univ. Wyoming.

Beetle, A.A., and A. Young. 1965. A third subspecies in the Artemisia tridentata complex. Rhodora 67:405-406. 
Bunting, S.C., B.M. Kilgore, and C.L. Bushey. 1987. Guidelines for prescribed burning sagebrush-grass rangelands in the northern Great Basin. USDA Forest Serv. Gen. Tech. Rep. INT-231.

Goodrich, S., E.D. McArthur, A.H. Winward. 1985. A new combination and a new variety in Artemisia tridentata. Great Basin Natur. 45:99-104.

Hagerman, A.E. 1987. Radial diffusion method for determining tannin in plant extracts. J. Chem. Ecol. 13:437-449.

Hagerman, A.E., and K.M. Klucher. 1986. Tannin-protein interactions. p. 67-76. In: J.B. Harbone and E. Middleton (eds.) Plant flavonoids in biology and medicine: biochemical, pharmacological, and structureactivity relationships. Alan $R$. Liss, Inc. New York.

Hironaka, M., M.A. Fosberg, and A.H. Winward. 1983. Sagebrush-grass habitat types of southern Idaho. Forest, Wildlife, and Range Exp. Sta. Bull. 35. Univ. Idaho, Moscow.

Jones, J.B., Jr. 1977. Elemental analysis of soil extracts and plant tissue ash by plasma emission spectroscopy. Commun. Soil Sci. Plant Anal. 8:349-365.

Julkunen-Tiitto, R. 1985. Phenolic constituents in the leaves of northern willows: methods for the analysis of certain phenolics. J. Agr. Food Chem. 33:213-217.

Kelsey, R.G., W.E. Wright, F. Sneva, A. Winward, and C. Britton. 1983. The concentration and composition of big sagebrush essential oils from Oregon. Biochem. Syst. Ecol. 11:353-360.

McArthur, E.D., C.L. Pope, and D.C. Freeman. 1981. Chromosomal studies of subgenus Tridentatae of Artemisia: evidence for autopolyploidy. Amer. J. Bot. 68:589-605.

McArthur, E.D., B.L. Welch, and S.C. Sanderson. 1988. Natural and artificial hybridization between big sagebrush (Artemisia tridentata) subspecies. J. Heredity 79:268-276.

Schuman, G.E., M.A. Stanley, and D. Knudsen. 1973. Automated total nitrogen analysis of soil and plant samples. Proc. Soil Sci. Soc. Amer. $37: 480-481$.
Sookne, D., and A. Forsythe. 1988.t Tests. p. 143-149. In: W.J. Dixon(ed.) BMDP statistical software package. Univ. California Press, Berkeley.

Stevens, R., and E.D. McArthur. 1974. A simple field technique for identification of some sagebrush taxa..J. Range Manage. 27:325-326.

Tisdale, E.W. 1986. Canyon grasslands and associated shrublands of westcentral Idaho and adjacent areas. Forest, Wildlife, and Range Exp. Sta. Bull. 40. Univ. Idaho, Moscow.

USDA, Soil Conservation Service. In edit. Adams, Washington counties and adjacent areas soil survey.

Vande Casteele, K., H. Geiger, and C.F. Van Sumere. 1982. Separation of flavonoids by reversed-phase high-performance liquid chromatography. J. Chromatogr. 240:81-94.

Welch, B.L., and E.D. McArthur. 1979a. Feasibility of improving big sagebrush (Artemisia tridentata) for use on mule deer winter ranges. $p$. 451-473. In: J.R. Goodin and D.K. Northington (eds.) Arid land plant resources. Texas Tech. Univ., Lubbock.

Welch, B.L., and E.D. McArthur. 1979b. Variation in winter levels of crude protein among Artemisia tridentata subspecies grown in a uniform garden. J. Range Manage. 32:467-469.

Winward, A.H. 1970. Taxonomic and ecological relationships of the big sagebrush complex in Idaho. Ph.D. Diss. Univ. Idaho, Moscow.

Winward, A.H. 1980. Taxonomy and ecology of sagebrush in Oregon. Oregon Agr. Exp. Sta. Bull. 642. Oregon State Univ., Corvallis.

Winward, A.H., and E.W. Tisdale. 1969. A simplified chemical method for sagebrush identification. Forest, Wildlife, and Range Exp. Sta. Note 11. Univ. Idaho, Moscow.

Winward, A.H., and E.W. Tisdale. 1977. Taxonomy of the Artemisia tridentata complex in Idaho. Forest, Wildlife, and Range Exp. Sta. Bull. 19. Univ. Idaho, Moscow. 